\title{
Evaluating local vulnerability and organisational resilience to frequent flooding in Africa: the case of Northern Cameroon
}

\author{
Henry Bang, Lee Miles, Richard Gordon \\ Disaster Management Centre, Bournemouth University, Dorset, Poole, BH12 5BB UK
}

\begin{abstract}
:
Purpose

The purpose of this paper is to evaluate local vulnerability and organisational resilience including coping/adaptive capacity to climate risks, specifically frequent flooding in Northern Cameroon.

Design/methodology/approach

The research is exploratory/deductive, and draws upon qualitative methods, secondary and empirical techniques supplemented by semi-structured qualitative interviews with senior disaster managers. Secondary information sources, which include peer review articles, government reports/plans, newspaper articles and other grey literature, enhanced the analysis.

Findings

The research findings have unveiled the physical and social vulnerability of Northern Cameroon to frequent flooding. Results also show that institutional performance for flood management in Cameroon is ineffective, and adaptive capacity is highly deficient. Cameroon's legislative framework for flood management is weak, and this exacerbates the poor implementation of structural and non-structural flood management measures. Results also indicate issues with relief, evacuation and foreign assistance in flood management. Recommendations that focus on enhancing capacity of response to frequent flooding via reducing vulnerabilities, managing resilience and enhancing adaptive capacity are provided.

Originality/Value

Using Gallopin's (2006) model of vulnerability, this article makes a distinct contribution by offering insights into the role of adaptive capacity in disaster management systems in developing (African) countries via an evaluation of vulnerabilities and organisational resilience to repeated flooding in Northern Cameroon.

Type of Paper
\end{abstract}

This is a case study research involving two areas in Northern Cameroon.

Keywords: vulnerability, organisational resilience, adaptive capacity, capacity of response, disaster management, floods

\subsection{Introduction}

Climate change is one of the greatest dangers facing humanity this century that deserves our immediate attention (Phil, 2018). There is discernible climate change induced increase in the frequency and intensity of floods in cities worldwide (Dobraszczyk, 2017; IPCC, 2014). Despite unprecedented breakthroughs in scientific and technological knowledge, damages/losses from frequent flooding are rising worldwide, and are not so far countered sufficiently by adequate disaster risk reduction (DRR) strategies (UNISDR, 2015). This is principally due to lack of adequate knowledge, weak understanding of vulnerabilities to hazards/disasters and unsatisfactory mitigation strategies (Twigg, 2009). Moreover, the impact of flooding is disproportionate in global terms; with developing countries hit hardest (CRED/UNISDR, 2016). Hence, understanding the different dimensions of vulnerability and resilience to natural hazards remains a continual challenge (Menoni 
et al., 2012). As climate change causes the world to be progressively unsafe, it is imperative to apply future-oriented measures to identify the impacts of future disasters (Ardeshir and Katayoun, 2018).

The concept of vulnerability is a broad, appropriate framework for considering fundamental direct and indirect causes of disasters. Yet, relatively few vulnerability researchers investigate the repetitive impact of hazards on some localities, and this seems to be the case with floods. Few studies, for example, consider the impact of frequent flooding on more vulnerable disaster management (DM) systems, like those in Africa.

Indeed, if Africa is to be the land of the future, its leaders and the wider society should be engaged in conscious foresight, mitigating negative drivers and risks through positive actions (Olugbenga and Geci, 2011). In fact, foresight should take place at the prevention stage in the conventional DM cycle to prevent a catastrophe happening as a result of a natural hazard (Ardeshir and Katayoun, 2018). Therefore, proactive action is vital to mitigate the ramifications of floods, which are the most frequent and widespread disaster in Africa (CRED/UNISDR, 2016).

Between 2000 and 2015, floods affected more than 373,176 people in Cameroon (Guha-Sapir et al., 2016) - escalating over time from merely having nuisance value to now having catastrophic implications. Therefore, as argued elsewhere, frequency is an issue needing further attention (Miles et al., 2017).

This article seeks to make a distinct contribution by offering more detailed insights into the role of adaptive capacity (AC) in DM systems in Cameroon via an evaluation of vulnerabilities and organisational resilience to repeated flooding in Northern Cameroon using Gallopin's (2006) model of vulnerability. In addition, the aim is to identify knowledge gaps in understanding of vulnerability and resilience to flooding in the Cameroon in order to inform flood policy and set a framework for future research.

\subsection{Conceptual basis: vulnerability, resilience and adaptive capacity within the context of natural hazards}

In recent years, three terms are often used and associated repeatedly and often interchangeably with studies of flooding - namely, vulnerability, resilience and AC. Nevertheless, these three terms have become broad terminology lacking unified definitions (Wisner et al., 2012). It is thus appropriate to set out the conceptual landscape of this article and in particular the value of utilising Gallopin's conceptual framework as a way to link the three concepts. 
There are numerous conceptualisations of vulnerability to natural hazards (Cardona, 2004; Wisner et al., 2004; Adger, 2006; Wisner et al., 2012) without a consensus on the meaning of the term (Menoni et al., 2012; Wisner et al., 2012). A synopsis of the definitions has been provided by some authors including Thywissen (2006) and Gaillard (2010). Nevertheless, the United Nations International Strategy for Disaster Reduction (UNISDR) has a universally accepted definition of the term: 'The conditions determined by physical, social, economic and environmental factors or processes, which increase the susceptibility of a community to the impact of hazards' (UNISDR, 2015: 10). Hence, vulnerability is identifying sensitivity and exposure to certain perturbations, disturbances and hazards. This definition underpins the context of vulnerability in this article.

Like vulnerability, resilience is a complex and multifaceted concept with varied definitions. Yet, for consistency, the conceptualisation of resilience applied in this article will be the one synonymous with the Sendai Framework for DRR. Indeed, the framework conceptualises resilience as: 'The ability of a system, community or society exposed to hazards to resist, absorb, accommodate and recover from the effects of a hazard in a timely and efficient manner, including through the preservation and restoration of its essential basic structures and functions' (UNISDR, 2015: 9). Resilience assumes then - at least in the Gallopin context - that the emphasis is on restoring stability. However, some scholars have argued that resilient systems should do more than return to the status quo (Coetzee et. al., 2018; Chelleri et al., 2015). While it is important to retain functions, the ability to incrementally adapt or transform are central components of resilience systems (Zebrowski, 2016; Chandler, 2014; Meerow et al., 2015; Brown et al., 2012).

For this article, the focus on resilience boils down to two dimensions - organisational and community. First, there is a need to create organisational resilience with stable institutions, frameworks and procedures/plans so that a country is better prepared to tackle subsequent hazards as well as stable channels to use/share multi-disciplinary knowledge for contingency planning towards hazard mitigation and preparedness (Allen, 2006; Smit and Wandel, 2006; Tschakert, 2007; UNISDR, 2015). Second, community resilience is conceptualised as how communities can strengthen their DRR capacities (Natassia et al., 2017; Twigg, 2009) including the potential to absorb shock, to learn from, adapt to, and recover from or 'bounce back better' after an event (Manyena, 2006; Gardner and Denkens, 2007).

In the face of the threat of rising floodwaters, transformational change will be undoubtedly required in the face of a new global climatic order. Indeed, Climate Change presents multiple challenges to 
regions/cities - not only in terms of resilience or sustainability, but also in relation to how urban inhabitants imagine they might adapt to a future transformed environment (Dobraszczyk, 2017). AC is often discussed in relation to other concepts such as sensitivity, vulnerability, susceptibility, coping range/ability, impact potential, robustness, critical levels, responsiveness, stability, resilience, flexibility and adaptability (Adger et al., 2005; Tompkins and Adger, 2005; Adger, 2006; Füssel and Klein, 2006; Smith and Wandel, 2006;). The concept also relates to the potential/ability to adapt/adjust to change, and take advantage of opportunities (Gallopin, 2006) and to better deal with problematic exposures and sensitivities (Smith and Wandel, 2006). Community AC reflects a region's enabling socio-economic, institutional and political environment and can respond to changes in social, economic, political and institutional conditions overtime (Smith and Wandel, 2006; Wisner et al., 2012).

The above briefly reviewed concepts of vulnerability, resilience and AC underpin this article, and are analysed within Gallopin's (2006) vulnerability framework in the case study of frequent flooding in northern Cameroon.

\subsection{Linking vulnerability, resilience and adaptive capacity}

Gallopin (2006) used a systemic perspective to identify and analyse the conceptual relations among vulnerability, resilience, AC within socio-ecological systems (see Figure 1). The model shows a linked system of 'AC' and 'resilience' that is a subset of 'capacity of response' in a central vulnerability system with 'sensitivity' and 'exposure' as other components. Resilience and AC are linked components of vulnerability associated with the capacity of social systems to restore stability and respond to change.

Figure 1. Conceptual Relations among vulnerability, resilience, and AC after Gallopin (2006)

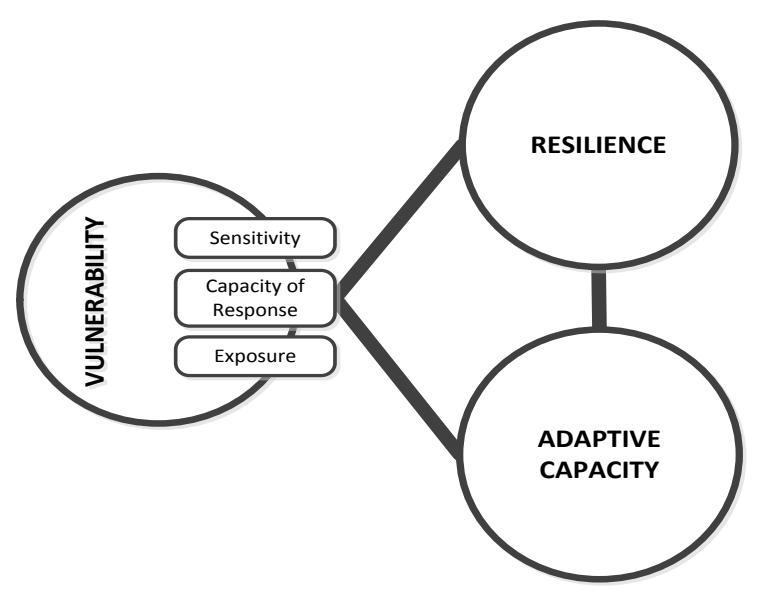


Gallopin (2006) also views social capital and AC as components of either 'resilience' or 'vulnerability' or both. Vulnerability then is a function of 'sensitivity', 'capacity of response' and 'exposure' and is conceptualised as the propensity of a system to suffer significant transformations because of its interaction with external or internal processes or events. 'Sensitivity' is considered as the degree to which the system is modified or affected by an external or internal disturbance (Gallopin, 2006: 295), and is therefore different from the system's 'capacity of response' that is also separate from 'exposure'. 'Exposure' means the degree, duration, and/or extent in which the system is in contact with, or subject to any disturbances or perturbation (Gallopin, 2006: 296).

Yet, of particular importance for this article, Gallopin defines 'capacity of response' as: 'the system 's ability to adjust to a disturbance, moderate potential damage, take advantage of opportunities, and cope with the consequences of a transformation that occurs'(Gallopin, 2006: 296). Hence, Gallopin is able to link the identification and accommodation of disturbance (vulnerability) with the sub-sets of the desire to create stability and moderate damage (resilience) as well as the desire to learn and improve (AC) within his component concept of Vulnerability known as the 'capacity of response'. These linkages and relations have implications for the analysis in this study (see Figure 8).

Cameroon is vulnerable to various types of hazards (Bang, 2016), with floods being the most frequent and repetitive on an annual basis, induced by heavy rains/thunderstorms often with devastating consequences (Bang et al., 2017). In particular, the 2012 floods that hit Northern Cameroon in August/September were the worst for more than 60 years according to Cameroon's Directorate of Civil Protection (DCP). The flooding exerted infrastructural and agricultural damage worth billions of CFA, disrupted communication and the reopening of the 2012/2013 school year. Furthermore, it caused a cholera and measles outbreak, killed more than thirty people, displaced about 60,000 and affected between 25,000-30,000 people (Cameroon Tribune, edition of 16 September 2012; UNICEF, 2012; Bang et al., 2017).

\subsection{Methodology}

\section{Case study: study areas in Northern Cameroon}

A case study research design was used to evaluate flood management in the Garoua and Maga areas in the North and Far North Regions of Cameroon respectively. The two settlements were chosen because both have been experiencing frequent annual flooding during the rainy seasons, have agrarian economies and were the hardest hit during the August/September 2012 (Bang et al., 2017). This approach is central to understanding institutional practices, policies, and the behaviour of disaster authorities (Louis et al., 2006). 
Garoua (see Figure 2), the most densely populated town in Cameroon, is the capital of the North Region. The town is an economic hub and host to the Société de Développement du Coton (SODECONTON), a parastatal responsible for producing and marketing cotton, the main cash crop in the region (Gergely, 2009; MINADER, 2014). The Benue River, which meanders on an extensive floodplain, dominates Garoua's drainage, including the Lagdo Dam built on it.

Figure 2. Map of Garoua showing flooded areas during the 2012 floods.

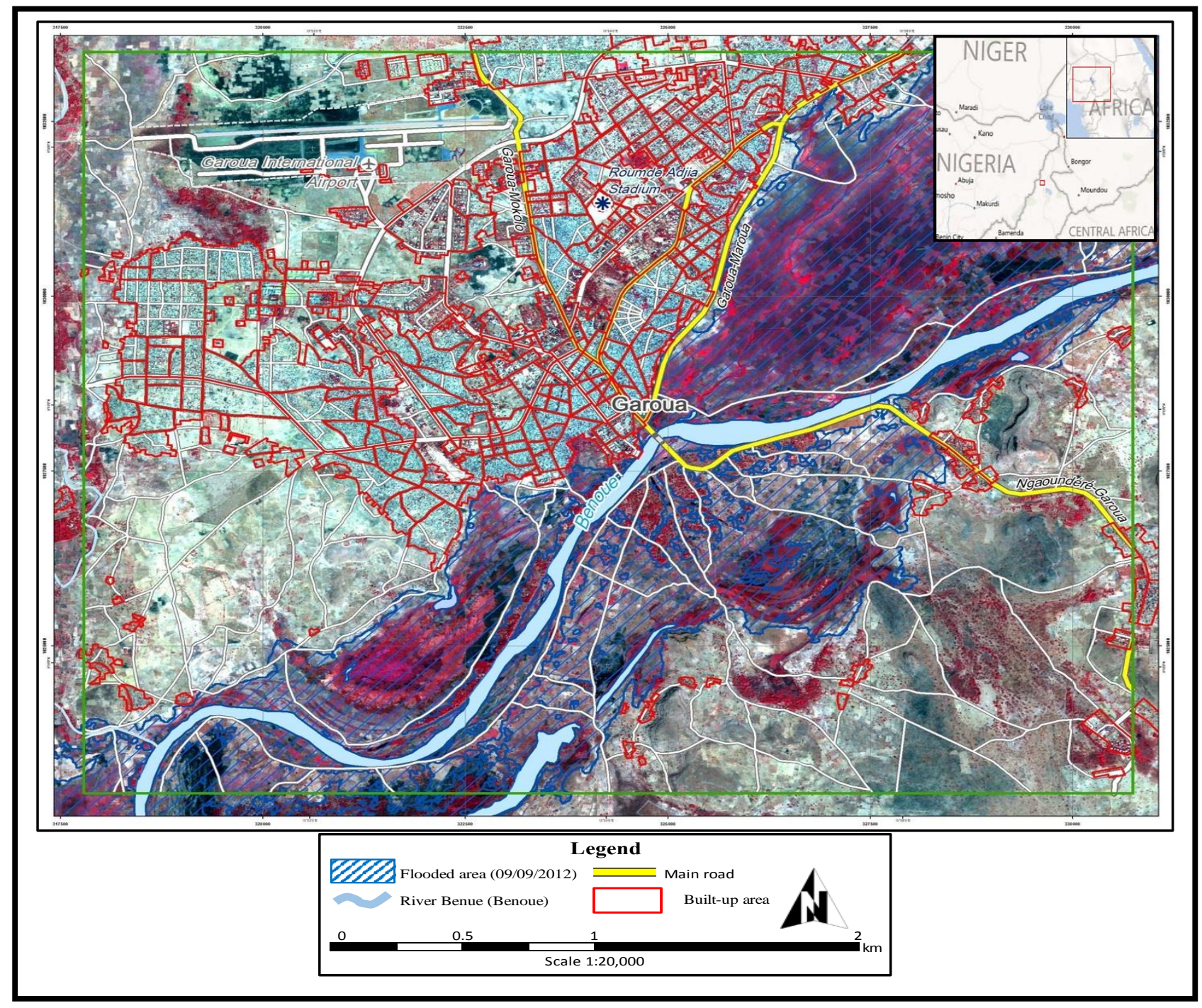

Source: Adapted from the European Union, (http://emergency.copernicus.eu/mapping/list-ofcomponents/EMSR019)

Maga (see Figure 3) is a rural settlement about 80kms East of Maroua, the capital of the Far North Region. Situated on the Waza Logone flood plain, Maga is home to the Sociétéd 'Expansion et de Modernisation de la Riziculture de Yagoua (SEMRY), a government parastatal in charge of managing rice production, the second most important cash crop in Northern Cameroon. The River 
Logone and Maga Dam influence the drainage, rice cultivation and flooding in this area (Loth, 2004; World Bank, 2013).

Figure 3. Map of Maga showing Lake Maga and flooded areas during the 2012 floods.

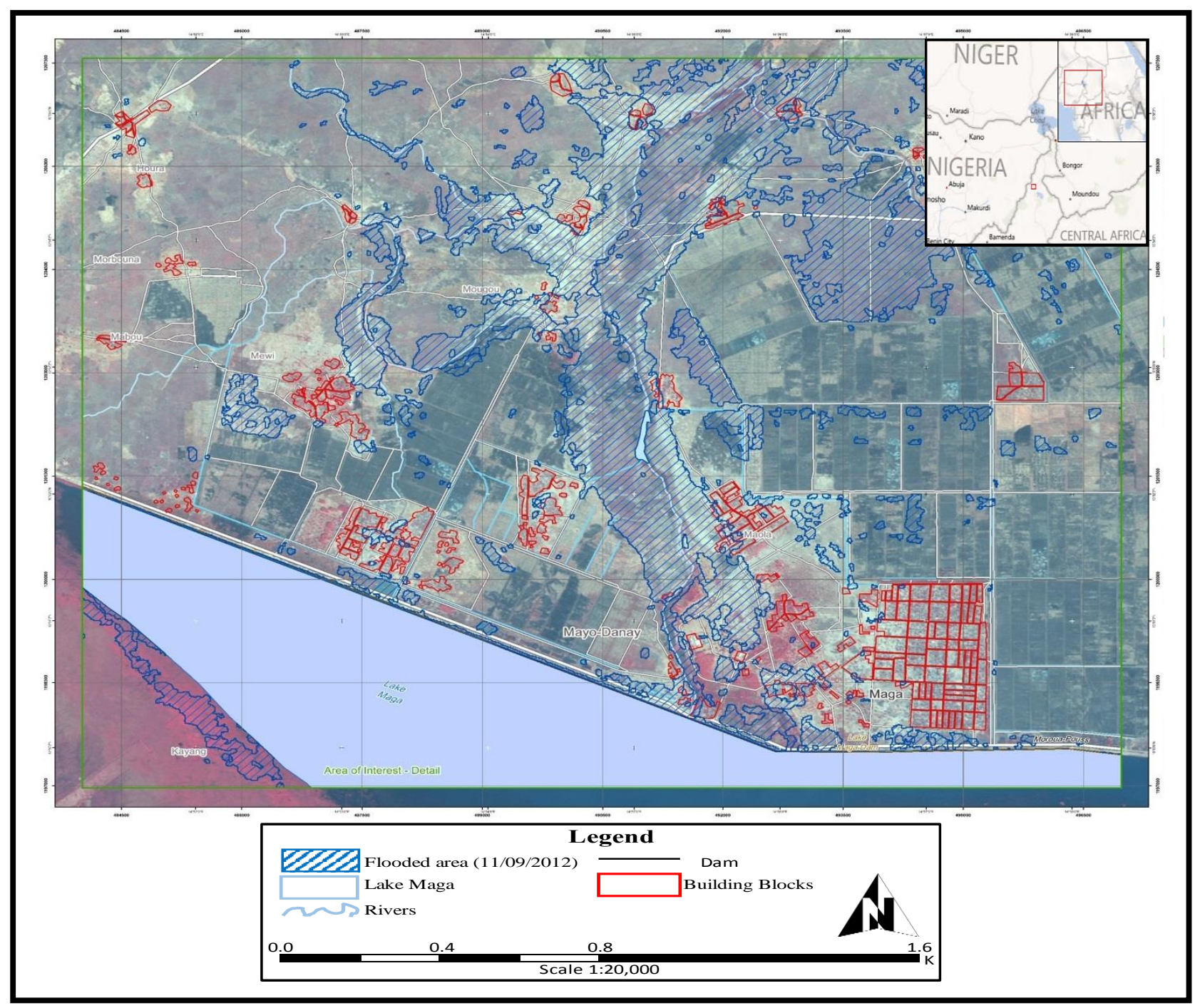

Source: Adapted from the European Union (http://emergency.copernicus.eu/mapping/list-ofcomponents/EMSR019)

Northern Cameroon is generally very hot and dry, characterised by desertification. More than $90 \%$ of the inhabitants engage in farming. Both cash crops (cotton and rice) and other staple foods are cultivated (Bassett and Turner, 2007; Gergely, 2009). The region is also a tourist attraction with some of Cameroon's best parks and nature reserves (Kimbu, 2011).

This exploratory and deductive research draws mainly on qualitative instruments using secondary and primary techniques. The primary research involved face-to-face and remote interviews with twelve senior disaster managers in Cameroon between March-June 2017 selected via a snowball sampling method. Semi-structured interview questions were used and the interviewees were offered 
anonymity to encourage sincere and frank responses. Question themes focused on socio-economic and cultural variables that influence social/physical vulnerability, adaptive capacity and organisational resilience to flooding from a DM perspective. Secondary information sources were peer-reviewed articles, government reports/plans and grey literature-newspaper articles. The data identified core concepts, themes and plans/programs that have informed the design of the research, including the analysis (Yin, 2003; Bhattacherjee, 2012).

By adopting this conceptual design, we acknowledge that the research can be enhanced by incorporating the views of the populations in the study areas. However, we view this research as exploratory to scope out the nature and extent of the variables that influence vulnerability and resilience to flooding. This can serve as a useful precursor to more detailed explanatory research involving interviews/surveys with the flood affected populace of northern Cameroon.

\subsection{Research findings}

Two vulnerability types - social and physical - as well as organisational resilience within Cameroon's DM framework (see Figure 8) are important for analysis. They represent the focus of the 'capacity of response' in the Cameroon case. Addressing these issues requires understanding of the hazards in northern Cameroon (frequent flooding) in addition to identifying opportunities for reducing community vulnerability within Cameroon's DM framework.

\section{Social vulnerability}

In the adapted framework, social vulnerability encapsulates various characteristics that include livelihood capabilities, resilience/resistance, well-being, social protection, political/social networks and institutions and political will to implement DRR measures. Indeed, social vulnerability is influenced by age, gender, health status, race, ethnicity, family structure, and access to resources, equity, poverty, power and residential location (Menoni et al., 2012; Wisner et al., 2012).

\section{Poverty}

All respondents $(100 \%)$ agree that the northern regions have the highest incidence of poverty and host the poorest people in Cameroon (see Figure 4; IMF, 2010; MINADER, 2014; World Bank, 2016). Moreover, the Boko Haram attack in northern Cameroon that spilled over from Nigeria is weakening the social cohesion in the region (ADB, 2015). $83.3 \%$ of respondents affirm that poverty and weak social networks reduce coping capacities and recovery abilities from natural hazards, and are central to other vulnerabilities regarding floods (Wisner et al., 2012). 
Figure 4. Poverty incidence and depth of poverty in North Cameroon from 2001-2014

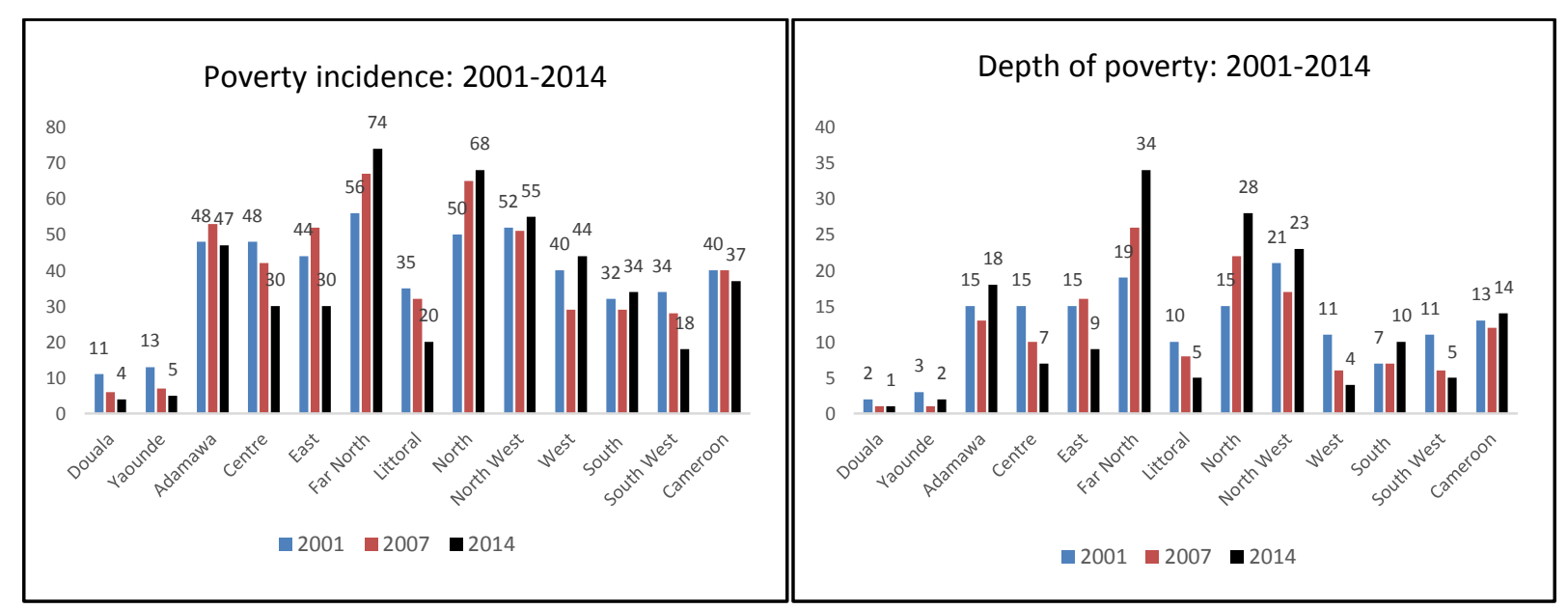

Source: World Bank (2016).

\section{Gender disparities and low educational attainment}

The northern regions have the lowest literacy rates and the weakest ratio of primary school enrolment (see Figure 5). The reason, according to interviewees (66.7\%), is that the inhabitants are traditionally Muslims, whose culture/tradition/religion encourages marriage at an early age. This causes many families not to send their female children to school (Carpenter, 2006; IMF, 2010). Consequently, these regions record the highest number of infant/child marriages in Cameroon (Carpenter, 2006; UNICEF, 2012), and the lowest literary and under-employed rate amongst women (ADB, 2015). Low educational attainment and gender divide increases vulnerability to flooding since the people are less empowered to tackle floods (Schneiderbauea and Ehrlich, 2006)

Figure 5. Literacy amongst women and median years of schooling by region

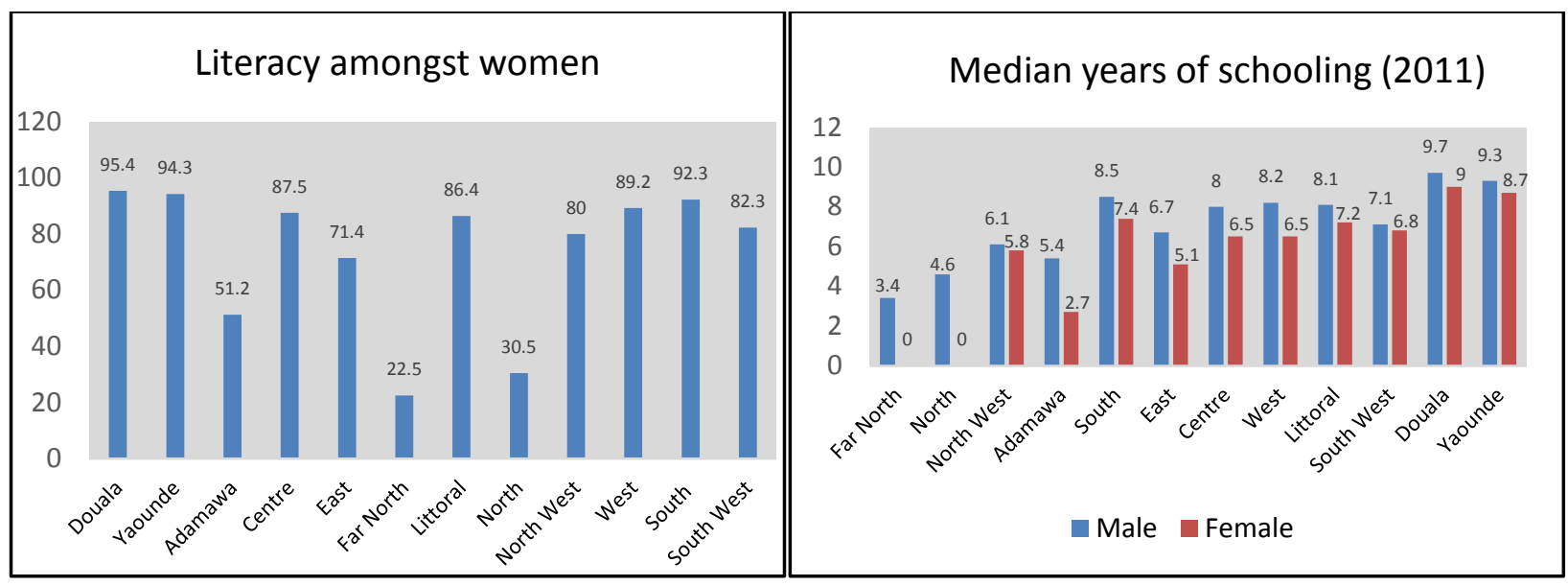

Source: World Bank (2016) 


\section{Access to drinking water and health hazards}

The northern region have the lowest access to safe drinking water in the country with only one of every four households (15-30\%) having access to safe drinking water (IMF, 2010; UNICEF, 2012). Administrators stated that floodwaters exacerbate the water scarcity, which compromise proper hygiene and sanitation, and increase the health problems of the local inhabitants. Furthermore, frequent flooding events are associated with recurrent water-borne diseases and consequently health risks. The rate of malnutrition in the area is also the highest in Cameroon (over 44\%), well above the national average of 31.7\% (Cartwright et al., 2013; World Bank, 2016; see Figure 6) while malaria causes between 35-40\% of the overall number of deaths (Ndassa et al., 2007, UNICEF, 2012). Most interviewees $(91.6 \%)$ highlighted that poor health/fatalities placed greater pressure on household budgets in terms of added costs for medication, and exacerbated by increased frequency of flooding.

Figure 6. Acute malnutrition by region

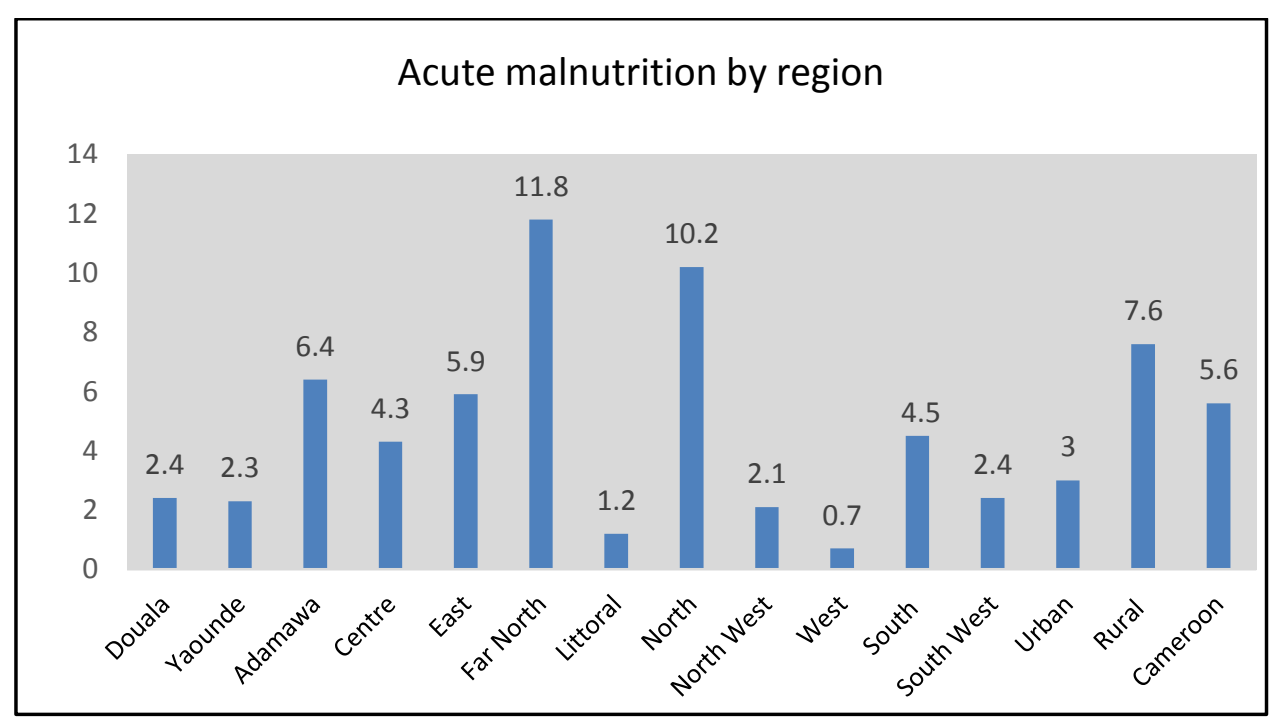

Source: World Bank (2016).

\section{Rapid population growth}

Northern Cameroon is the most populated region in the country (NIS, 2016). The fertile flood plains of the regions' rivers attract high population densities, exacerbated, according to all interviewees, by refugees fleeing the crisis in the Central African Republic, and the Boko Haram insurgency in Northern Nigeria. This assertion has been confirmed in other studies (ADB, 2015; Bang et al., 2017). The population growth has increased agrarian activities leading to land degradation/erosion, which increases flooding (Tchindjang et al., 2012). 


\section{Trans-boundary insecurity}

Senior government officials interviewed, reveal that insecurity is rife in Northern Cameroon because of the Nigerian based Boko Harams' terrorist activities in the region that poses a serious threat to social cohesion. They further asserted that the insecurity was creating an environment where people and the government are less able to carry out DRR measures. Indeed, fragile and conflict-affected areas typically have lower capacity to cope with natural hazards (Peters, 2017).

\section{Physical vulnerability}

Physical vulnerability encompasses exposure of people, physical and environmental assets to geological/natural/environmental hazards. It also relates to human occupancy of unsafe/risky areas/zones; damage caused due to the frequency, severity and attributes of hazardous eventsrelated to the sensitivity and exposure component of vulnerability (Cutter, 2006: Wisner et al., 2012). According to Gallopin, physical vulnerability is also closely associated with 'capacity to respond' in the framework (see Figure 8) because it also involves analysis/assessment of exposed assets and disaster severity.

\section{High frequency of flooding}

Disaster managers disclosed that in the last decade, the frequent annual flash floods occurring in the region had often-causing socio-economic and physical damages, especially recently urbanised settlements in marshy areas experiencing high population growth. Continuous disruption, damage and destruction of properties ensure that the population never have time to recover from these impacts and suffer extreme sensitivity (see framework as in Figure 8) - constantly drawing them into a vicious cycle of destitution and poverty.

\section{Locations of houses and their construction materials}

The location of dwellings (exposure component in framework) also influences the community's susceptibility to flooding. Many houses are built in poorly drained areas. Respondents confirmed these houses are easily flooded even with low water-level rise after heavy rains. To worsen the situation, the houses are built of weak construction materials that easily collapse when flooded (Bang et al. 2017). The inability to locate suitable construction land in safer areas alongside poor housing infrastructure is linked to poverty (Wisner et al., 2012).

\section{Deteriorating hydraulic infrastructures}

A major contributor to flooding in northern Cameroon is the inadequate, insufficient, and deteriorating hydraulic infrastructure of the Lagdo and Maga Dams, and the Logone Dyke due to lack 
of maintenance (Interviewees, World Bank, 2013). There are notable structural defects (Saborio and Mora, 2012; see Table 1). For example, the Maga dam showed disturbing indications of an impending failure that include piping, overtopping, and surface erosion (see Figure 7). Consequently, these structures are very vulnerable to damage during flooding. Overall, there is clear evidence of strong awareness of social and particularly physical vulnerability in northern Cameroon.

Table 1: Structural defects in the Maga dam and the Logone dyke in Northern Cameroon.

\begin{tabular}{|c|c|c|}
\hline $\begin{array}{l}\text { Hydraulic } \\
\text { Structure }\end{array}$ & Defects & Cause \\
\hline \multirow[t]{9}{*}{ Maga Dam } & $\begin{array}{l}\text { - Numerous piping holes / internal erosion close } \\
\text { to the spill way and Mayo Vrick channel. }\end{array}$ & - Formed during the 2012 flooding \\
\hline & - Piping holes & $\begin{array}{l}\text { - Due to poor compaction works between compacted } \\
\text { layers during the initial construction. }\end{array}$ \\
\hline & $\begin{array}{l}\text { - Substantial subsurface seepage along the } \\
\text { length of the dam. }\end{array}$ & - Lack of a cut-off trench \\
\hline & $\begin{array}{l}\text { - Significant erosion on upstream slope of the } \\
\text { embankment, particularly around irrigation } \\
\text { intakes and spillway }\end{array}$ & - Wave impact \\
\hline & $\begin{array}{l}\text { - Downstream slope shows intensive and deep } \\
\text { gullies }\end{array}$ & $\begin{array}{l}\text { - Caused by waves overtopping the top of the dam, } \\
\text { including wind and rain erosion. }\end{array}$ \\
\hline & $\begin{array}{l}\text { - Crest of Dam subsided by around } 20-50 \mathrm{~cm} \text { in } \\
\text { many sections over the years. }\end{array}$ & $\begin{array}{l}\text { - Holes in Dam created by termites and human } \\
\text { activities. }\end{array}$ \\
\hline & - Small holes in the Dam & \\
\hline & $\begin{array}{l}\text { - Concrete walls in some sections of the dams } \\
\text { have been vandalised. }\end{array}$ & $\begin{array}{l}\text { - Boulders placed downstream for energy dissipation } \\
\text { and erosion control were vandalized. }\end{array}$ \\
\hline & $\begin{array}{l}\text { - Volume or carrying capacity of the Mayo } \\
\text { Vrick channel was greatly reduced }\end{array}$ & - Channel is blocked by sedimentation and vegetation \\
\hline \multirow[t]{2}{*}{$\begin{array}{l}\text { Logone } \\
\text { Dyke }\end{array}$} & $\begin{array}{l}\text { - Crest and height of the Logone dyke reduced } \\
\text { to less than a meter in many places }\end{array}$ & $\begin{array}{l}\text { - This is due to river overtopping, water erosion and } \\
\text { human activities. }\end{array}$ \\
\hline & $\begin{array}{l}\text { Risk of complete collapse of Logone river } \\
\text { bank in many locations }\end{array}$ & $\begin{array}{l}\text { - Severe erosion was noted along the Logone river } \\
\text { bank for a length of around } 3.5 \mathrm{~km} \text { of the } \\
\text { embankment }\end{array}$ \\
\hline
\end{tabular}

Source: Authors, compiled from a range of sources including Saborio and Mora (2012), World Bank (2013).

Figure 7. Pictures showing deterioration of the Maga Dam

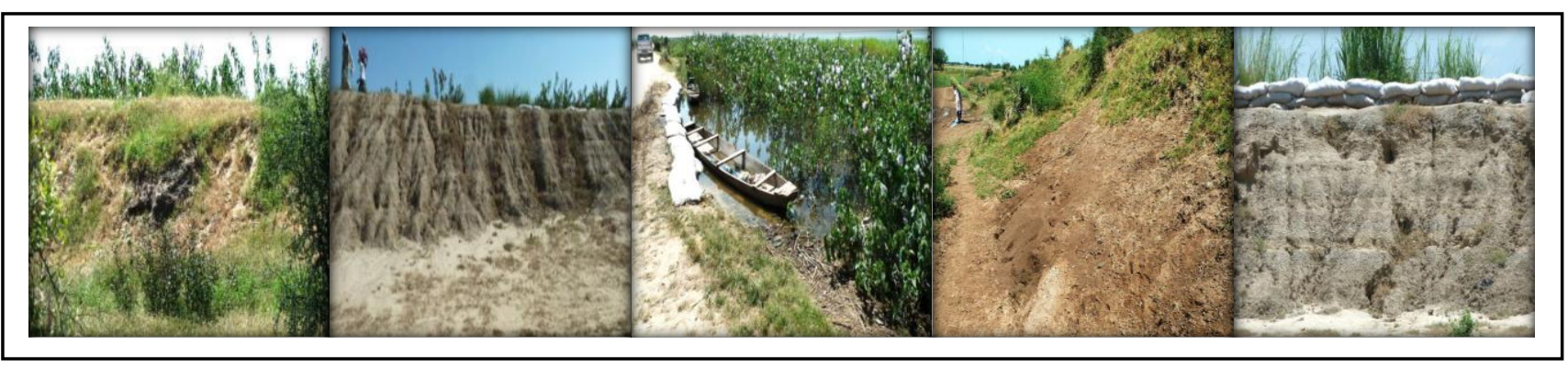

Source: Saborio and Mora (2012). 


\section{Resilience to flooding in Cameroon}

After discussing vulnerability aspects, attention will now focus on findings relevant to resilience and AC dynamics outlined in Gallopin's adapted framework.

\section{Flood management in Cameroon}

Flood management in Cameroon is under the auspices of civil protection, considered a service that protects people and property against the entire hazard types. In Cameroon, there exist legislative frameworks and institutional platforms for disaster mitigation, prevention, preparedness, and recovery. In theory then, Cameroon possesses a stable framework supporting organisational resilience that is designed to promote stability and to build back better after disaster. However, the practice leaves much to be desired (Bang, 2016).

\section{Legislative framework}

Cameroon's legislative framework for civil protection comprises of various laws, decrees, presidential and prime ministerial instructions. Officially, the general national strategy on the prevention and management of the various risks in Cameroon emphasises disaster mitigation, prevention, emergency response and rehabilitation (see Table 2). Analysis of the legislative framework, however, revealed gaps that hinder effective flood management in Cameroon and practical organisational resilience is poor overall.

First, there is weak incorporation of DRR approaches into legislation, often leading to a more reactive, than proactive flood risk management (Bang et al., 2017). This has also implications for community resilience, since no clear plans exist in the legislative framework to strengthen the capacity of regional/local community structures to effectively cope with, resist or recover from floods. Overall, then the system has rather low resilience capacity (see Figure 8) ensuring that the country has not so far achieved sustainable flood risk management. 
Table 2: General strategy for the prevention of risks and disaster management in Cameroon

\begin{tabular}{|c|c|c|}
\hline $\begin{array}{l}\text { Disaster } \\
\text { Management } \\
\text { Phase } \\
\end{array}$ & Key Action & Activities \\
\hline $\begin{array}{l}\text { Before a hazard } \\
\text { or disaster }\end{array}$ & $\begin{array}{l}\text { - Ensure a National } \\
\text { Risk Observatory } \\
\text { is operational }\end{array}$ & $\begin{array}{l}\text { - Establish a contingency plan designed to obtain, analyse, and } \\
\text { disperse information on the major risks in an effort to protect } \\
\text { populations and minimise any impacts on life and property }\end{array}$ \\
\hline During a crisis & $\begin{array}{l}\text { Develop an } \\
\text { Emergency } \\
\text { Intervention plan }\end{array}$ & $\begin{array}{l}\text { - Help the affected populations } \\
\text { - Monitor the disaster } \\
\text { - Assist victims }\end{array}$ \\
\hline After a disaster & $\begin{array}{l}\text { - Sensitise and } \\
\text { educate affected } \\
\text { population about } \\
\text { the risky zones. }\end{array}$ & $\begin{array}{l}\text { - Produce a map of the various risks in the area } \\
\text { - Guide against subsequent dangers } \\
\text { - Reinforce the preventive action of citizens } \\
\text { - Initiate rehabilitation measures }\end{array}$ \\
\hline
\end{tabular}

Source: Authors, adapted from Bang (2016)

Second, although the legislative framework envisages decentralized organisational structures for the management of natural hazards, it does not provide effective funding mechanisms for the DCP. Most interviewees (83.3\%) highlighted that funds for disaster emergency assistance are only made available on an ad hoc basis from the national level. This causes delay in the sourcing and transfer of funds rendering crisis response ineffective with dire consequences for disaster victims (Bang, 2016).

Third, the legislative framework has a narrow focus on flood response rather than a comprehensive flood DRR strategy. A policy statement on the National Plan for the Management of the Environment simply states 'Participation, prevention and management of natural catastrophes and risks' without mentioning floods as a priority hazard (Sighomnou, 2005: 3). Interview respondents (75\%) also confirmed that little had changed even by 2017.

Fourth, legislation does not emphasis structural mitigation measures considering that hydrological structures are exacerbating flooding, especially in northern Cameroon where the dams/dykes have deteriorated considerable. To mitigate flood risks in the region there need to be constant monitoring and repair of the structures (World Bank, 2013).

\section{Organisational and administrative framework}

The organisational structure and management of the various risks and hazards/disasters in Cameroon have an administrative architecture that exists at the national, regional, and local levels, under the auspices of the Ministry of Territorial Administration and Decentralisation (MTAD). Governors, Senior Divisional Officers, and Divisional Officers head the Regions, Divisions and Sub-Divisions respectively. These administrators also double as the chief disaster managers in their areas of jurisdiction. The governance structure has a hierarchical top-down power structure from the national 
to local level. A crisis committee, however, can be created at the local level although the devolution of resources for crisis management to local structures is limited, rendering the current framework ineffective (Bang, 2016).

According to the interviewees (91.6\%), multiple ministries handle flood management with varied and sometimes conflicting interests undermining organisational resilience. These are the Ministry of Environment and Forests with interest in environmental conservation; the Ministry of Mines, Water and Energy, which has interest in water resources management; the Ministry of Agriculture that is interested in agricultural production and water availability; the Ministry of Scientific Research and the Ministry of Higher Education, with research interests on water related issues (Sighomnou, 2005). With these varied interests, no institution leads or even has a comprehensive flood risk policy. Indeed, a senior disaster manager said the 2012 floods took Cameroon's DM institutions unawaresthe authorities lacked a clear flood risk-reduction strategy.

\section{Deficiencies in crisis communication and blame}

Deficiencies in organisation resilience extend to crisis communication. When the 2012 flash floods arrived, for example, the government created a crises committee in the region that held regular meetings chaired by the Governors. Yet, the official channel of communication with the affected population, however, was via the Minister of Communication, located in Yaoundé about 1,150kms away, holding press conferences in the capital. The minister recounted government promises and plans: most notably the provision of 123 billion CFA francs to aid flood victims, to relocate displaced victims, provide relief assistance and to ensure the 2012/2013 school year started unhitched (Alertnet News, edition of October 25, 2012).

Senior government officials blamed the flooding on nature (extreme weather conditions, heavy rains, and Climate Change) and thus sought to move attention away from issues of weak organisational resilience and avoid censure for failures to institute adequate DRR measures. For example, the lack of contingency emergency plans for the frequent volcanic eruptions on Mt Cameroon reinforces blames framing centred on incompetency rather than incapacity (Miles et al., 2017).

\section{Adaptive capacity: the experience of the 2012 floods}

Findings from the interviews (75\%) also highlight key weaknesses in terms of AC and in particular, the ability to learn from frequent flooding in the case of northern Cameroon - with particular deficiencies evidenced in relation to appraisal, relief and foreign assistance. 


\section{Issues of flood impact appraisal}

Shortly after reports of 2012 floods emerged, the DCP, the Ministry of Basic Education and the Ministry of Environment and Nature Protection sent personnel to assess the flooding, focusing on different aspects. The education ministry was more concerned with the damage to educational establishments, and the threat posed to the start of the 2012/2013 academic year while the environment and nature protection ministry evaluated the impact on the environment and ecosystems (UNICEF, 2012). The DCP focused on the population affected/displaced. However, there was weak co-ordination of these ongoing appraisals - and according to the majority of interviewees (83.3\%), information on flooding impact remained largely piecemeal and unstructured, with little coherence in transmitting immediate challenges and long-term impacts, undermining AC.

\section{Issues of relief and evacuation}

Lack of co-ordination and information sharing also inhibited other aspects of AC, particularly the responsiveness of key decisions and reactivity of Cameroon DM. In the case of 2012, three issues were revealed. First, there was - according to the interviewees - slow decision making; the late evacuation of the flood-affected populace was less effective, since some distraught families feared delay and had already sought temporary accommodation in unflooded primary schools and churches. Second, the lateness of government provided financial and material help to the affected/displaced people ensured that flood impacts had often taken its toll on the population. Third, not all the flood victims that deserved relief aid received it. Almost all the respondents (91.6\%) said this was probably due to embezzlement, which is characteristic of post-DM in Cameroon (Bang, 2016).

\section{Issues of foreign assistance}

Weaknesses in AC were also illustrated in issues concerning foreign assistance. According to $66.6 \%$ of the interviewees, securing foreign assistance was largely presented in terms of addressing social and particularly physical vulnerability rationales. Cameroon's Ministry of the Economy, Planning and Regional Development requested credit to the amount of US\$ 108 million from the World Bank to repair damaged hydraulic infrastructures; to foster more effective flood disaster risk management and to ensure sustainable water management in northern Cameroon (World Bank, 2013). Even when secured, there is also the issue of appropriate disbursement of foreign assistance forwards. Additionally, post-flooding assistance have also been provided by the UNHCR, WFP, UNICEF, WHO, UNDP, the governments of Morocco, Japan and NGOs such as PLAN and the Red Cross (Cameroon Tribune, edition of October 26, 2014). Some respondents (50\%) alleged that the government uses crisis to seek for financial assistance, which is often utilised for other purposes. Yet, 
very little of the assistance according to the interviews has been used to enhance the learning, training and competencies of Cameroon's disaster managers and thus a key issue of AC remains unaddressed.

\section{Lessons learned post-2012 flood}

Post-2012 flood management in Northern Cameroon was skewed towards addressing physical vulnerabilities. With funds obtained from the World Bank, the government awarded a contract worth US\$ 72 million to repair the hydraulic infrastructures in the Far North Region damaged by the 2012 floods. Repair works on the Maga dam and Logone dyke were undertaken (Saborio and Mora, 2012; World Bank, 2013). There is clear evidence then of some attempts at addressing physical vulnerabilities in Northern Cameroon.

However, on social vulnerability, resilience and AC, the effectiveness of government measures is much less clear. In 2014, the MTAD created a committee known as 'Coordination and Follow-up Committee on Managing Relief Assistance and Assisting Flood Victims'. The committee's objectives were to ensure all flood victims received compensation; assess the total cost of homes, farms, and social infrastructure destroyed in the two regions by floods; resettle the affected people; rehabilitate hydro-meteorological stations and repair damaged roads in the region (Cameroon Tribune, edition of October 26, 2014). However, all the respondents showed much more guarded and cautious responses and the effectiveness of these measures is yet to be fully determined.

\section{Flood monitoring and early warning system}

Monitoring and early warning systems for flood hazard mitigation are still weak in Cameroon (Bang et al., 2017). In the Far North Region, only eight rainfall stations are available, with limited operational capacity. Respondents said rivers in the region are not gauged and that prior to the 2012 floods, a flood early warning system did not exist. The findings suggest that - during the 2012 floods - the hydro-meteorological station at Yagoua in the Far North Region was not operational. Moreover, data for the operational rainfall stations is transmitted infrequently, not systematically shared by government agencies, and is not captured and analysed systematically (World Bank, 2013).

\section{Applying the conceptual framework to the Cameroon}

The findings of this research have been presented via an analysis based on Gallopin's (2006) adapted framework (see Figure 8) in order to map, highlight and interpret key attributes of vulnerability, resilience and AC systems relevant for the case study in the Garoua and Maga areas of northern Cameroon. 
Figure 8. Conceptual framework for vulnerability in Northern Cameroon. Source: Authors, adapted from Gallopin (2006).

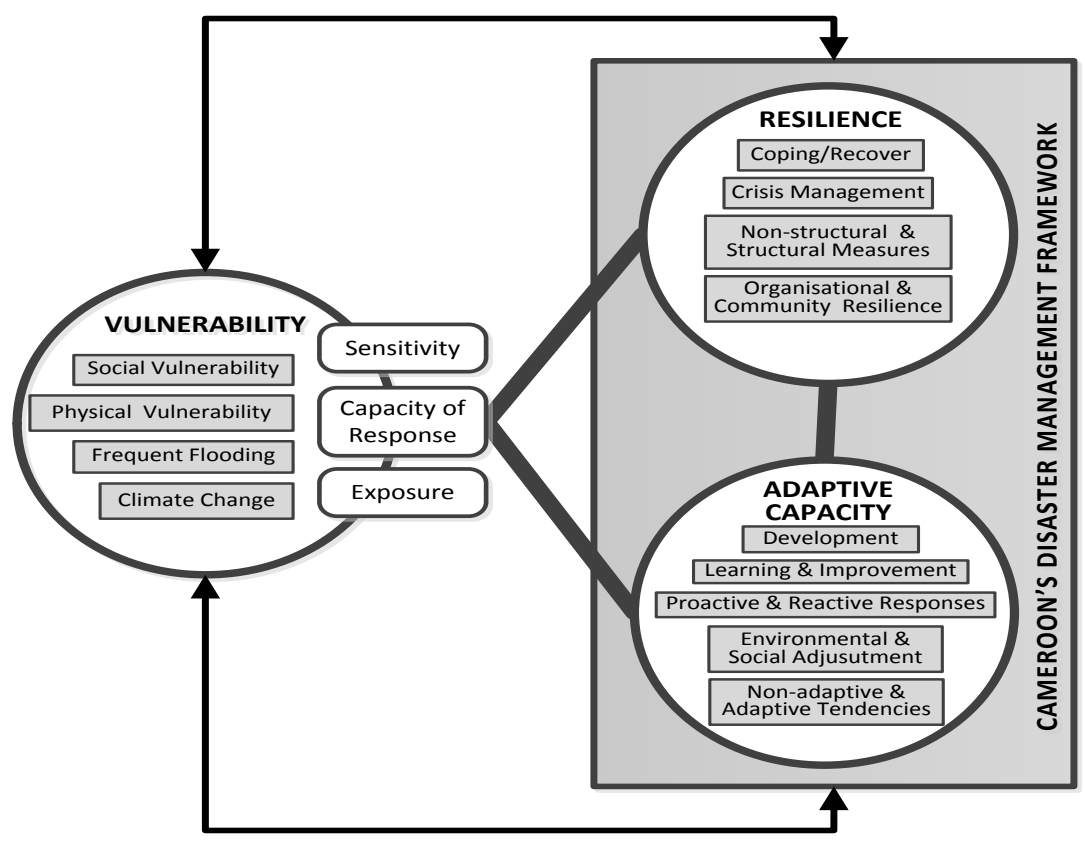

The adapted framework highlights Resilience and AC as important DM/DRR strategies within Cameroon's DM framework, which falls within the component of 'capacity of response' that is able to mitigate or reduce vulnerability. We assumed that exposure to frequent flooding increases the sensitivity of the system and reduces capacity of response. Therefore, resilience and AC represent the system's ability to respond to frequent flooding in hazardous and vulnerable conditions. We would argue that resilience and AC are complementary and relative in the model, and the emphasis is to build hazard resilient and adaptive communities. In this regard, enhancing people's resilience and AC can only result from addressing the root causes of vulnerability.

\subsection{Discussion and conclusions}

This article has used Gallopin's (2006) vulnerability model to provide a reliable diagnosis of vulnerability and resilience to frequent flooding in northern Cameroon. Research findings have unveiled the outstanding physical vulnerability of the region, and with it, the high degree of sensitivity and exposure to hazards. Often cited were concerns over the location of weak houses in flood prone areas, and the fragile state of the hydraulic infrastructures. The findings also show the imprint of such extreme physical vulnerabilities on Gallopin's 'capacity to response' when applied to Cameroon. Although the government blamed an inability to address the physical vulnerabilities due to limited financial resources (Saborio and Mora, 2012; World Bank, 2013), in reality, government's negligence, incompetence, and corruption are to blame. 
Social vulnerability also prevails. The high incidence of poverty and a high population density, low educational attainment, poor cultural practices and the prevalence of endemic diseases are increasing social vulnerability in northern Cameroon. When applying Gallopin's ideas, this rising social vulnerability also impacts on 'capacity of response' since the ability of the densely located populace to stabilise conditions and then bounce forward (resilience) is limited given, for example, that the population is susceptible to disease. Equally, the low educational attainment severely restricts the ability of the populace to be involved in $\mathrm{AC}$ in order to meet the challenges of frequent flooding.

The analysis also reveals that institutional performance for flood management in Cameroon is ineffective. This is surprising because despite the very high physical/social vulnerability of the region, the evidence shows that the authorities have been unable to learn, enhance and engage effective flood DRR strategies. Drawing from Gallopin's model, the implication is that AC through learning and improvement is highly deficient. These findings suggest that - in line with Gallopin's concept of resilience - this unstable level of organisational resilience diminishes Cameroon's capacity to response to frequent flooding.

Findings have also revealed that Cameroon's flood management legislative framework is weak again highlighting deficient organisational resilience and poor AC (see Figure 2). The roles of the other agencies that collaborate with the DCP on flood mitigation are not addressed in legislation. More so, no systematic procedural and/or organisational methods exist for assessing institutional influences on key vulnerabilities, and consequently, on the risk of flood-related disasters; severely inhibiting learning and review which is, according to Gallopin, a key feature of practical AC. $75 \%$ of the primary interviews also identified that devolution of responsibilities, authority, and competencies, to lower administrative levels and the local governance of disaster risks is limited in Cameroon with most decision-making being formalised and centralised at least in terms of disaster response. Hence, the ability to harness localised community resilience - another key feature of Gallopin's notion of resilience - (see Figure 1) is severely curtailed.

Shortcomings in the management of North Cameroon's drainage system have also been exposed, especially the lack of a comprehensive hydro-meteorological services and real time data to address rainfall variability, and sustainably manage flooding in the region. This is in breach of national frameworks that emphasise an operational hazard monitoring and early warning service that can be used to warn/educate 'at risk' populations, and as an adequate risk aversion tool for hydraulic infrastructures 
The analyses also show negligence in managing the hydraulic infrastructures. This is a major flaw because the hydrological regime of the entire catchment area and its drainage system keeps changing with increases in the frequency and intensity of rainfall/storms. To protect the population and their livelihoods from flooding, safety measures also have to keep pace with environmental changes (World Bank, 2013). However, there are some positive signs. Findings indicated that post-2012 flood management is improving with mostly structural mitigation measures announced, without much consideration for social vulnerability. Nevertheless, the creation of a permanent coordination and follow-up committee to manage relief aid are good signs. The success of these measures, will only be assessed when the next major crises happens. There is at least some attempt then in Cameroon to enhance some organisational resilience - via new more stable structures - and to build some limited AC - essential ingredients of a more effective capacity of response according to Gallopin. Nevertheless, the strong appreciation for vulnerability is not evenly matched or balanced by measures aimed at enhancing resilience (organisational and community) or AC (learning and review) in the Cameroon case.

A key issue is that the government attempted to shift blame for challenges faced in managing the 2012 floods to the frequency of floods in the region and climate change. In some ways, the DM system cannot cope with the frequency and intensity of external events (Miles et al., 2017). In such circumstances, Cameroon's continuing weak and imbalanced capacity of response against such frequent 'forces of nature' will most likely lead to blame avoidance on the grounds of incapacity (Brändström, 2016). The reality in the Cameroons, however, is that the dire flood impact was a result of ineffective disaster and water resources management, including the poor implementation of both structural and non-structural flood DRR measures.

\section{$6 \quad$ Recommendations}

The recommendations are based on the findings, analysis, and discussions and focus on enhancing 'capacity of response' via reducing vulnerabilities, managing resilience and enhancing AC. The following recommendations are based on addressing physical vulnerability: (1) urgent repair works and new structural designs are needed in the hydraulic structures of north Cameroon. An additional spillway and overtopping resistance structures should be constructed in the Maga Dam to avoid downstream flooding. (2) Land use regulatory policies should be implemented in risky areas to control settlement expansion, institute building standards and discourage the construction of buildings in flood-prone areas. (3) Cameroon's DM legislation needs updating to identify and isolate clearly all flood risk zones in the country, develop preparedness plans and provides user-friendly flood risk information in different areas. 
The next recommendations, which are based on social vulnerability and addressing wider resilience and $\mathrm{AC}$ contexts, ultimately require the authorities to have a strong political will to implement adequate DRR measures (Wisner et al., 2012). (4) The government should regularly conduct a multidisciplinary and cross-sectoral post-disaster review to identify any lessons that can inform future organisational and community resilience initiatives. (5) In line with Gallopin's resilience, the government needs to prioritise resilience programs, plans, and investments in all the phases of the DM cycle with a view to providing an effective and stable institutional and organisational capability. (6) The government should inculcate disaster vulnerability reduction within the development planning of the country, including supportive social, cultural and economic policies that counter social vulnerability, reduce poverty, and increase community resilience via access to education and health services. (7) There is need for new community resilience building initiatives - recognising that resilience should not only be a top-down process, but that the local vulnerable communities and organisations should be supported via greater education on appropriate risk-reduction/preparedness for frequent flooding. (8) As part of Gallopin's AC, the government needs to focus on developing a continuous process of learning and review for Cameroon's disaster managers and DM frameworks. Indeed the learning can be via a greater use of simulations and training in order to make the disaster managers more agile and adaptive in dealing with future floods and finding best possible workarounds. (9) An agenda to educate local community/religious leaders could play a pivotal role for societal mobilisation against gender inequality that undermines female teenagers in the region. By taking this approach and using Gallopin's concepts to inform professional practice, there is at least a better chance that Northern Cameroon will benefit from a stronger capacity of response to the evergrowing challenges of frequent and catastrophic flooding in the future.

\section{References}

ADB (2015), "Cameroon: joint 2015-2020 country strategy paper and country portfolio performance review report", available at: https://www.afdb.org/fileadmin/uploads/afdb/Documents/Project-andOperations/Cameroon_-_Joint_2015 2020_Country_Strategy_Paper_and_Country_Portfolio_ Performance_Review_report_\%E2\%80\%93_06_2015.pdf (accessed 3rd February, 2017)

Ardeshir, S., Katayoun J., (2018) "Towards a customized foresight model on "disaster risk management" in developing countries", Foresight, https://doi.org/10.1108/FS-01-2018-0002

Adger, W. (2006), "Vulnerability”, Global Environmental Change, Vol. 16 No. 3, pp. 268-281.

Adger, W., Hughes, T., Folke, S., Carpenter S., Rockström, J. (2005), “Social-ecological resilience to coastal disasters", Science, Vol. 309 No. 5737, pp. 1036-1039.

Allen, K. (2006), “Community based disaster preparedness and climate adaptation: local capacity building in the Philippines", Disasters, Vol. 30 No. 1, pp. 81-101. 
Bassett, T., Turner, M. (2007), "Sudden shift or migratory drift? Fulbe herd movements to the Sudano-Guinean region of West Africa”, Human Ecology, Vol.1 No. 35, pp. 33-49.

Bang, H., Miles, L., Gordon, R. (2017), "The irony of flood risks in African dryland environments: human security in North Cameroon", World Journal of Engineering and Technology Vol. 5.3B, pp. 109-121.

Bang, H. (2016), 30 Years after the Lake Nyos Disaster: What prospects for rehabilitation and reintegration in the Region? Disaster management, social vulnerability, risk perception and relocation decisions in Cameroon, Book Venture Publishing, US.

Bhattacherjee, A. (2012), Social science research: principles, methods, and principles (2nd ed.). Create Space Independent Publishing Platform, Tampa, Florida.

Brandström, A. (2016), Crisis, accountability and blame management. CRISMART, Stockholm.

Brown, A., Dayal, A., Rumbaitis Del Rio, C. (2012). "From practice to theory: Emerging lessons from Asia for building urban climate change resilience", Environment and Urbanization, Vol. 24 No. 2, pp. 531-556. http://dx.doi.org/10.1177/ 0956247812456490

Carpenter, B. (2006), "Women's literacy in Ngoundere, Cameroon. Independent study project collection, available at: http://digitalcollections.sit.edu/cgi/viewcontent.

cgi ?article $=1256 \&$ context $=$ isp_collection $($ accessed 18th November, 2017)

Carpenter, R., Walker, B., Anderies, M., Abel, N. (2001), "From metaphor to measurement: resilience of what to what?", Ecosystems, Vol. 4, pp. 765-781.

Cardona, O. (2004), "The need for rethinking the concepts of vulnerability and risk from a holistic perspective: a necessary review and criticism for effective risk management", in Bankoff, G., Frerks, G., and . Hilhorst, G. (Eds), Mapping Vulnerability: Disasters, Development and People, Earthscan, London, pp. 37-51..

Cartwright, E., Patel, K., Mbopi-Keou, F., Ayers, T., Haenke, B., Wagenaar, B., Mintz, E., Quick, R. (2013), "Recurrent epidemic cholera with high mortality in Cameroon: persistent challenges 40 years into the seventh pandemic", Epidemiology and Infection, Vol. 141 No.10, pp. 2083-2093.

Chandler, D (2014) Resilience: the governance of complexity. Routledge, London,

Chelleri, L., Waters, J., Olazabal, M., Minucci, G. (2015), “ Resilience trade-offs: addressing multiple scales and temporal aspects of urban resilience, Environment and Urbanization, Vol. 27 No. 1, pp. 181-198. http://dx.doi.org/10.1177/ 0956247814550780

Coetzee, C., Van Nierkerk, D., Raju, E (2018) "Reconsidering disaster resilience: a nonlinear systems paradigm in agricultural communities in Southern Africa", Natural Hazards, Vol. 90 No. 2, pp. 777-801.

Cutter, S. (2006), Hazards, vulnerability and environmental justice. Earthscan Publication, Sterling, London 
CRED/UNISDR (2016), “The human cost of weather related disasters 1995-2015”, available at: https://www.unisdr.org/2015/docs/climatechange/COP21_Weather

DisastersReport_2015_FINAL.pdf (accessed 3rd March, 2018)

Dobraszczyk, P. (2017), "Sunken cities: climate change, urban futures and the imagination of Submergence", International Journal Of Urban And Regional Research, Vol. 41 No. 6, pp. 868-887

Füssel, H., and Klein, T. (2006), "Climate change vulnerability assessments: an evolution of conceptual thinking”, Climatic Change, Vol. 75 No. 3, pp. 301-329.

Gaillard, J. (2010), "Vulnerability, capacity, and resilience: perspectives for climate and development policy", Journal of International Development, Vol.22 No. 2, pp. 218-232.

Gallopin, G. (2006), “Linkages between vulnerability, resilience and adaptive capacity”, Global Environmental Change, Vol.16 No. 3, pp. 293-303.

Gardner, J., Denkens, J. (2007), "Mountain hazards and the resilience of social ecological systems: lessons learned in India and Canada", Natural Hazards, Vol. 41 No. 2, pp. 317-336.

Gergely, N. (2009), “The cotton sector of Cameroon. Africa Region”, Working Paper Series No. 126, World Bank, USA

Guha-Sapir, D., Below, R., Hoyois, P. (2016), “EM-DAT: The CRED/OFDA International Disaster Database: Université Catholique de Louvain, Belgium", available at http://www.emdat.be/ (accessed 8th August, 2017)

IMF (2010), “Cameroon: poverty reduction strategy paper", available at https://www.imf.org/external/pubs/ft/ scr/2010/cr10257.pdf ( accessed 2nd May, 2017).

IPCC. (2014), "Climate change 2014: synthesis report”, in Pachauri, K., Meyer, L. (Eds), Contribution of Working Groups I, II and III to the Fifth Assessment Report of the Intergovernmental Panel on Climate Change, Geneva, Switzerland.

Kimbu, A. (2011), "The role of transport and accommodation infrastructure in the development of eco/nature tourism in Cameroon", Tourism Analysis, Vol. 16 No. 2, pp. 137-156.

Loth, P. (2004), "The return of the water: restoring the Waza Logone floodplain in Cameroon", available at http://www.atl.org.mx/files/WaterPublications/ParaCuencas/6.pdf (accessed 15th April, 2018)

Louis, L., Nikitina, E., Kotov, V., Manuta, J. (2006), “Assessing institutionalized capacities and practices to reduce the risks of flood disasters", in Birkman, J. (Ed), Measuring vulnerability and coping capacity to hazards of natural origin: concepts and methods, UNU Press, Japan, pp. 359-379.

Manyena, S. (2006), “The concept of resilience revisited”. Disasters, Vol.30 No.4, pp. 433-450.

Menoni, S., Molinari, D., Parker, D., Ballio, F., Tapsell, S. (2012), “Assessing multifaceted vulnerability and resilience in order to design risk-mitigation strategies”, Natural Hazards, Vol. 64 No.3, pp. 2057-2082. 
Miles, L., Gordon, R. and Bang, H. (2017), "Blaming active volcanoes or active volcanic blame? Volcanic crisis communication and blame management in the Cameroon", in Fearnlay, C., Bird, D. Jolly, G. Haynes, K., McGuire, B. (Eds), Observing the volcano world: volcano crisis communication, pp. 395-408. Springer, Cham.

Miles, M., and Huberman, M. (1994), Qualitative data analysis ( $2^{\text {nd }}$ ed.). Sage Publications, Thousand Oaks, CA

MINADER (2014), "Overview of the status of Cameroonian cotton (Crop Year 2012-2013)", available at: https://www.icac.org/wp-content/uploads/2012/07/Cameroon_E.pdf (accessed 19th July, 2016)

Natassia, G., Salmon, P., Spencer, C., McArdle, D., Archer, F. (2017), "Defining disaster resilience: comparisons from key stakeholders involved in emergency management in Victoria, Australia", Disasters, Vol. 41 No.1, pp. 171-193.

NIS (2016), "Characteristics of the population of Cameroon, available at: https://knoema.com/atlas/sources/National-Institute-of-Statistics-Cameroon (accessed 14th June 2017)

Ndassa, A., Mimpfoundi, R., Gake, B., Martin, M., Poste, B. (2007), "Risk factors for human schistosomiasis in the upper Benue valley, in northern Cameroon", Ann Trop Med Parasitol, Vol. 101 No. 6, pp. 469-77.

Olugbenga, A, Geci, K., (2011). "Is Africa the land of the future? It is not a given!", Foresight, Vol. 13 No. 3, pp. 3-6, https://doi.org/10.1108/14636681111138721

Peters, K. (2017), "The next frontier for disaster risk reduction: tackling disasters in fragile and conflict-affected contexts", available at: https://www.odi.org/sites/odi.org.uk/files/resourcedocuments/11808.pdf (accessed 9th May 2018)

Phil, T., (2018) "Facing disaster: the great challenges framework", Foresight, https://doi.org/10.1108/FS-04-2018-0040

Saborío-Bejarano, J., Mora-Castro, S. (2012), "Evaluation de l'etat du barrage, des digues, du reservoir et des structures hy-drauliques du systeme de maga-logone-vrick". Situation Hydrologique, Geotechniqueet, available at: https://www.gfdrr.org/sites/default /files/publication/Cameroon_Technical_evaluation_dam.pdf (accessed 9th May, 2017)

Sighomnou, D. (2005), “Cameroon: integrated flood management in River Logone Flood-Plain, available at: http://www.apfm.info/publications/casestudies /cs_cameroon_syn.pdf (accessed 26th November, 2019).

Meerow, S., Newell, J., Stults, M. (2015). "Defining urban resilience: a review”, Landscape and Urban Planning, Vol. 147, pp. 38-49.

Smit, B., Wandel, J. (2006), “Adaptation, adaptive capacity and vulnerability”, Global Environmental Change, Vol.16 No. 3, pp. 282-292.

Tompkins, L., and Adger. W. (2005), "Defining response capacity to enhance climate change policy”, Environmental Science \& Policy, Vol. 8 No. 6, pp. 562-571. 
Thywissen, K. (2006), "Core terminology of disaster reduction: a comparative glossary", in Birkmann, J. (Ed), Measuring vulnerability to natural hazards, United Nations University Press, New York, pp. 448-496.

Tschakert, P. (2007), "Views from the vulnerable: understanding climatic and other stressors in the Sahel”, Global Environmental Change, Vol.17 No. 3-4, pp. 381-396.

Twigg, J. (2009), "Characteristics of a disaster-resilient community: a guidance note (version 2)", DFID Disaster Risk Reduction NGO Interagency Group, Teddington, UK.

UNICEF (2012), "Flash floods in North Cameroon meet fast response from UNICEF Cameroon, available at: http://www.unicef.org/wcaro/english/4501_7022.html (accessed 12th June 2015)

UNISDR (2015), “Sendai framework for disaster risk reduction 2015-2030", available at: http://www.unisdr.org/files/43291_sendaiframeworkfordrren.pdf (accessed 15th March, 2018)

Wisner, B; Blaikie, P; Cannon, T; Davis, I. (2004), “At risk, natural hazards, people's vulnerability and disasters". Second Edition. London and New York: Routledge

World Bank (2016), "Republic of Cameroon: Priorities for Ending Poverty and Boosting Shared Prosperity. Systematic Country Diagnostic" available at:

https://openknowledge.worldbank.org/handle/10986/24697 (accessed 30th October, 2018)

World Bank (2013), “Cameroon-flood emergency project", available at: http://documents.worldbank.org/curated/en/449341468232165276/Cameroon-Flood-EmergencyProject (accessed 14th May, 2017)

Wisner, B. Gaillard, J., Kelman, I. (2012), "Framing disaster: theories and stories seeking to understand hazards, vulnerability and risk", in Wisner, B. Gaillard, C., Kelman, I. (Eds), The Routledge Handbook of Hazards and Disaster Risk Reduction, Routledge, London, pp. 18-34.

Yin, R.K. (2003), Case study research design and methods. Thousand Oaks, Sage, California

Zebrowski, C. (2016). The value of resilience: securing life in the 21st century. Routledge, New York 